\title{
EFEK TAYANGAN VIDEO PENJELASAN KASUS CORONA TERHADAP KHAYALAK (ANALISIS DESKRIPTIF KUANTITATIF TERHADAP EFEK VIDEO PENJELASAN KASUS CORONA DI PROVINSI BANTEN)
}

\author{
Ukon Furkon Sukanda, M.IKom \\ Ade Irfan Abdurahman, M.Si \\ Dosen Ilmu Komunikasi Universitas Islam Syekh Yusuf Tangerang
}

\begin{abstract}
ABSTRAK
Pro dan Kontra menerpa Gubernur Banten Wahidin Halim (WH) setelah mengumumkan 2 (dua) warga Provinsi Banten terkonfirmasi positif Corona Virus Disease (Covid)-19. Pengumuman diunggah di media sosial Instagram dan tersebar baik di media massa ataupun aplikasi chating. Dengan metode purposive random sampling melalui sebaran google form. Kami melakukan penelitian tentang efek tayangan video penjelasan kasus Corona di Banten terhadap khalayak yang berdomisili di Kota Tangerang. Dari data ini dapat disimpulkan bahwa sebaran video pernyataan Gubernur Banten Wahidin Halim tentang kasus di Provinsi Banten berefek besar terhadap efek kognitif afektif dan dan perilaku responden. Hal ini terlihat dari rata-rata jawaban tingkat persetujuan responden yang tinggi pada efek kognitif $(\mathrm{M}=2,30-3,30)$ afektif $(\mathrm{M}=2,50-3,02)$ dan perilaku $(\mathrm{M}=2,30-2,76)$.
\end{abstract}

\section{Pendahuluan}

Gubernur Banten Wahidin Halim

(WH) mengumumkan 2 (dua) warga Provinsi Banten terkonfirmasi positif Corona Virus Disease (Covid)-19, Kamis, 12 Maret 2020. Pengumuman tersebut disampaikan melalui video berdurasi 1 Menit 53 Detik yang beredar melalui WhatsApp (WA) dan Instagram (IG).

Berikut pengumuman lengkap Wahidin Halim soal dua orang warga Banten positif Corona: Assalamualaikum Warahmatullahi Wabarakatuh. Kepada warga Banten yang saya cintai. Saya kabarkan bahwa berdasarkan laporan dari tim kesehatan Banten, bahwa ada dua orang warga Banten yang positif terkena virus Corona. Mereka kebetulan baru saja melakukan perjalan dari Malaysia. Untuk itu, sebagai Gubernur Banten, saya berharap masyarakat tetap waspada dan jangan panik dan dengan menghindari pertemuan-pertemuan bersifat umum atau paling tidak menjauhi keramaian, agar kita bisa memastikan tidak tertular oleh virus Corona ini. Demikian yang bisa saya kabarkan semoga Allah SWT senantiasa melindungi kita, menyelamatkan kita dan menyelamatkan bangsa ini. (Kompas.com)

Tak lama berselang, WH kembali menyampaikan pengumuman melalui video berdurasi 2 Menit 10 Detik. Pada video ke dua, WH menyatakan ada penambahan 2 orang lagi warga Banten yang positif Corona. Pernyataan Gubernur Banten tersebut kemudian terpantau menyebar melalui sejumlah WA Grup dalam beberapa menit. Video pengumuman tersebut juga diunggah ke akun IG @wh_wahidinhalim dan menjadi bahan pemberitaan di sejumlah media massa.

"Saya kabarkan informasi terakhir, berdasarkan laporan tim kesehatan Provinsi Banten, baru saja dua orang warga Banten positif terkena Corona. Tetapi dalam perkembangannya terakhir, sudah ada empat orang warga Banten (positif Covid-19)," kata Wahidin Halim.Pria yang akrab disapa WH tersebut mengimbau kepada masyarakat Banten agar berhati-hati dan selalu waspada. Tidak mendatangi tempat-tempat keramaian dan pusat pertokoan. "Untuk mempertimbangkan melakukan perjalanan ke negara yang terkena wabah Corona. Semoga Allah menyelamatkan warga Banten dan memberikan kesehatan," katanya. (Suara.com)

"Berdasarkan laporan tim kesehatan Dinas Kesehatan Provinsi Banten, bahwa ada dua warga Banten yang 
positif terkena virus Corona. Mereka ini adalah, kebetulan baru saja melakukan perjalanan dari Malaysia," kata Gubernur Banten, Wahidin Halim, dalam video itu, Kamis (12/03/2020). Pada video yang diunggah dua jam lalu itu, dia mengimbau warga Banten untuk mengurangi aktivitas di luar ruangan, berkumpul di tempat umum dan keramaian. Ini guna mencegah penularan Covid-19. Sebenarnya, pemerintah pusat telah mengumumkan, keterangan valid terkait Covid-19 hanya diberikan oleh Juru Bicara Pemerintah dalam Penanganan Virus Corona Achmad Yurianto. (Liputan6.com)

Pengumuman yang disampaikan WH mengundang banyak reaksi dari berbagai pihak. Salah satunya dari Juru bicara penanganan wabah virus Corona_Achmad Yurianto yang merasa heran. "Gubernur Banten itu dapat dari mana meriksanya itu? Karena kami tidak pernah menyampaikan data ini kepada gubernur. Saya tidak tahu kalau beliau mendapat data sendiri, ya terserah," ujar Yurianto di Kompleks Istana Kepresidenan, Jakarta pada Kamis, 12 Maret 2020. Padahal, menurut Yurianto, pemerintah pusat tidak pernah memberikan data pasien positif Covid-19 kepada pemerintah daerah. Yurianto mengatakan, Kemenkes hanya akan memberikan data pasien Covid-19 kepada dinas kesehatan untuk kepentingan penelusuran kontak. "Kami tidak pernah memberikan data pada otoritas pemerintahan daerah," ujar dia. (Tempo.co)

Pengumuman yang dilakukan WH berselang 10 hari setelah Presiden Jokowi mengumumkan 2 warga Indonesia positif Corona. Pengumuman untuk peningkatan jumlah selanjutnya dilakukan oleh Satgas penanganan di tingkat pusat. Terlepas dari beragam kontroversi mengenai kewenangan $\mathrm{WH}$, pengumuman yang disampaikan melalui video pendek tersebut memicu reaksi spontan dari berbagai kalangan. Perkembangan teknologi memungkinkan video tersebar dengan cepat melalui aplikasi dan media sosial.
Video yang disampaikan juga menjadi bahan untuk media massa menerbitkan pesan komunikasi massa.

Dalam Ilmu Komunikasi, fenomena semacam ini dapat dikaji menggunakan Teori Stimulus-OrganismResponse (S-O-R). Model komunikasi SOR yang berhubungan dengan respon masyarakat. Teori ini merupakan proses komunikasi yang pada akhirnya menimbulkan reaksi khusus, sehingga seseorang dapat mengharapkan dan memperkirakan kesesuaian antara pesan dengan reaksi dari komunikan.

Teori yang ditemukan oleh Hovland (1953) ini awalnya berasal dari psikologi. Namun dalam perkembangannya digunakan dalam Ilmu Komunikasi. Unsur-unsur yang terdapat pada teori ini diantaranya pesan (Stimulus), komunikan (Organism) dan efek (Response). (Effendy, 2003: 254).

Stimulus merupakan rangsangan atau dorongan sehingga dalam teori ini isi pernyataan (message) menjadi unsur utamanya. Organism merupakan badan yang hidup, dalam hal ini adalah manusia atau dalam istilah komunikasi disebut dengan komunikan (penerima pesan). Yang terakhir Response yang merupakan pengaruh, tanggapan, reaksi, jawaban, efek atau akibat.

Teori S-O-R dalam proses komunikasi berkaitan dengan perubahan sikap yaitu aspek "how" bukan "what" atau "why". Lebih jelasnya, how to communicate dalam hal ini dimaksudkan dengan how to change the attitude, bagaimana mengubah sikap komunikan. Namun hal yang terpenting dan sangat ditekankan pada teori ini lebih kepada pesan yang disampaikan, apakah mampu menumbuhkan motivasi, menumbuhkan gairah kepada komunikan sehingga komunikan dapat dengan cepat menerima pesan yang telah diterima untuk kemudian terjadi perubahan sikap dan perilaku dari komunikan.

Menurut teori ini, organism menghasilkan perilaku tertentu jika ada 
kondisi stimulus tertentu pula. Efek yang ditimbulkan adalah reaksi khusus terhadaps timulus yang khusus pula. Sehingga seseorang dapat mengaharapkan dan menyesuaikan antara pesan dengan reaksi yang terlihat dari komunikan sebagai penerima pesan. Pendekatan yang ada pada teori S-O-R lebih mengutamakan cara-cara pemberian imbalan yang lebih efektif agar komponen konasi dapat lebih diarahkan pada sasaran yang diinginkan.

Teori S-O-R menjelaskan bagaimana suatu rangsangan yang pada akhirnya mendapatkan respon. Tingkat interaksi yang paling sederhana yang dapat terjadi melalui teori ini ialah ketika seseorang memberikan tindakan lalu kemudian terdapat respon yang diberikan oleh orang lain. Fisher berpendapat bahwa istilah S-R (Stimulus-Respon) dikatakan kurang tepat karena terdapat intervensi organisme antara stimulus dan respon. Maka dari itu akan dirasa lebih tepat jika menggunakan istilah S-O-R (StimulusOrganism-Response). Dalam proses perubahan sikap, sikap komunikan dapat berubah jika stimulus yang menerpannya benar-benar melebihi dari yang dialaminya. (Effendy, 2003)

Asumsi dasar dari Teori S-O-R adalah media massa menimbulkan efek yang langsung, cepat dan lebih terarah terhadap komunikan. Prinsip teori ini sesungguhnya dapat dikatakan sebagai prinsip yang sederhana. Yaitu respon sebagai reaksi balik dari individu ketika menerima stimulus dari media. Seseorang dapat memperkirakan suatu kaitan efek antara pesan-pesan yang ada di media massa dan reaksi dari audien, atau dapat pula dikatakan efek yang ditimbulkan adalah reaksi khusus terhadap stimulus. Respon yang pada akhirnya membuat seseorang dapat mengharapkan kesesuaian antara pesan dan reaksi pada komunikan. Dalam kehidupan bermasyarakat secara luas, prinsip stimulus-respon mengasumsikan bahwa pesan informasi dipersiapkan oleh media dan didistribusikan secara sistematis dalamskala yang luas. Dengan begitu pesan yang ada dapat disebarkan secara serempak dan diterima oleh khalayak dalamjumlah yang luas. Bukan hanya ditujukan pada individu atau perseorangan saja.

Teori S-O-R menjelaskan bahwa media massa memiliki efek yang sangat kuat dalam kehidupan bermasyarakat. Hal ini sesuai dengan kenyataan mengenai tingginya konsumsi terhadap media massa. Teori ini memandang media sebagai obat yang disuntikkan langsung ke dalam pembuluh darah audience untuk kemudian menimbulkan reaksi seperti yang diharapkan.

Apabila Teori S-O-R diterapkan pada masyarakat secara luas, maka terdapat prinsip yang harus digenggam yaitu pesan yang disiapkan, dibagikan dengan sistematis dan menyeluruh pada waktu yang bersamaan. Dengan adanya kemajuan teknologi diharapkan mampu membantu penyebarluasan dan pendistribusian pesan dengan tidak memihak sehingga akan ada sambutan dan tanggapan dari masyarakat. Dalam prinsip ini semua komunikan (penerima pesan) berada pada kedudukan yang sama dalam hal menerima pesan dan isi pernyataan yang telah disampaikan.

Dari konsep efek (Respon) penelitian ini mengekplorasi efek komunikasi massa kedalam dua efek komunikasi massa yaitu efek kognitif, afektif dan efek behaviour. Ketiga efek tersebut, senada pengelompokan konsep kecemasan menurut Gail W. Stuart (dalam Annisa \& Ifdil, 2016) yang juga dikelompokkan pada respon perilaku, kognitif, dan afektif;

1. Perilaku, diantaranya: 1) gelisah, 2) ketegangan fisik, 3) tremor, 4) reaksi terkejut, 5) bicara cepat, 6) kurang koordinasi, 7) cenderung mengalami cedera, 8) menarik diri dari hubungan interpersonal, 9) inhibisi, 10) melarikan diri dari masalah, 11) menghindar, 12) 
hiperventilasi, dan 13) sangat waspada.

2. Kognitif, diantaranya: 1) perhatian terganggu, 2) konsentrasi buruk, 3) pelupa, 4) salah dalam memberikan penilaian, 5) preokupasi, 6) hambatan berpikir, 7) lapang persepsi menurun, 8) kreativitas menurun, 9) produktivitas menurun, 10) bingung, 11) sangat waspada, 12) keasadaran diri, 13) kehilangan objektivitas, 14) takut kehilangan kendali, 15) takut pada gambaran visual, 16) takut cedera atau kematian, 17) kilas balik, dan 18) mimpi buruk.

3. Afektif, diantaranya: 1) mudah terganggu, 2) tidak sabar, 3) gelisah, 4) tegang, 5) gugup, 6) ketakutan, 7) waspada, 8) kengerian, 9) kekhawatiran, 10) kecemasan, 11) mati rasa, 12) rasa bersalah, dan 13) malu.

\section{HASIL DAN PEMBAHASAN}

Penelitian ini melakukan survei terhadap masyarakat di Kota Tangerang. Responden dipilih dengan metode purposive random sampling melalui google form yang disebarkan melalui aplikasi chating dan media sosial. Adapun kriteria responden adalah sebagai berikut:

1. Tinggal atau berdomisili di Kota Tangerang

2. Pernah menonton video pernyataan Gubernur Banten Wahidin Halim tentang kasus Covid-19 di Banten

Penelitian dilakukan dari tanggal 17 Maret 2020 - 26 Maret 2020, tersebar ke 140 responden. Dari 140 responden, 66 orang yang memenuhi kriteria dan menjadi responden yang jawabannya dianalisis dalam penelitian ini. Demografi Responden. Keseluruhan responden 53,0\% laki-laki, dan $47,0 \%$ perempuan. Dari aspek Usia, responden berumur 17-19 tahun 19,7\%,
20-29 tahun 59,1\%, 30-39 tahun 15,2\%, 40-49 tahun 3,0\%, 50-59 tahun 3,0\%. Selanjutnya kami melakukan analisis data untuk menjawab pertanyaan penelitian kami: Bagaimana efek tayangan video penjelasan Gubernur Banten Wahidin Halim tentang kasus virus Corona terhadap masyarakat Kota Tangerang? Dari pertanyaan penelitian tersebut, kami melakukan identifikasi masalah sebagai berikut:

1. Bagaimana video penjelasan Gubernur Banten Wahidin Halim tentang kasus virus Corona menerpa responden?

2. Bagaimana Efek Kognitif video penjelasan Gubernur Banten Wahidin Halim tentang kasus virus Corona memengaruhi responden?

3. Bagaimana Efek Afektif video penjelasan Gubernur Banten Wahidin Halim tentang kasus virus Corona memengaruhi responden?

4. Bagaimana Efek Perilaku yang mengaruhi responden setelah menonton video penjelasan Gubernur Banten Wahidin Halim tentang kasus virus Corona?

Adapun Hasilnya adalah sebagai berikut:

\section{Terpaan Media}

Bagan 1. mendeskripsikan analisis jenis media yang menjadi sumber informasi responden untuk menyaksikan video pernyataan Gubernur Banten tentang sebaran virus Corona di Provinsi Banten. Hasil Gambar 1 menunjukkan bahwa Media Sosial Instagram menjadi sumber informasi video $60,6 \%$, whatsapp $47 \%$, youtube $7,6 \%$, facebook $1,5 \%$ dan twitter

Bagan 1 Sumber Informasi $N=66$

$1,5 \%$. 
Dari mana anda menyaksikan atau menonton tay Wahidin Halim tentang sebaran Virus Corona di F 66 tanggapan

\begin{tabular}{|c|c|c|c|c|c|}
\hline & & $\begin{array}{c}\text { Frequen } \\
\text { cy }\end{array}$ & $\begin{array}{c}\text { Perce } \\
\text { nt }\end{array}$ & $\begin{array}{c}\text { Valid } \\
\text { Perce } \\
\text { nt }\end{array}$ & $\begin{array}{c}\text { Cumulati } \\
\text { ve } \\
\text { Percent }\end{array}$ \\
\hline $\begin{array}{l}\text { Vali } \\
\text { d }\end{array}$ & $\begin{array}{l}\text { Diputar } \\
\text { berulan } \\
\text { g kali }\end{array}$ & 2 & 3,0 & 3,0 & 3,0 \\
\hline & $\begin{array}{l}\text { Hanya } \\
\text { Sebagia } \\
\mathrm{n}\end{array}$ & 15 & 22,7 & 22,7 & 25,8 \\
\hline & $\begin{array}{c}\text { Menont } \\
\text { on }\end{array}$ & & & & \\
\hline & $\begin{array}{l}\text { Hingga } \\
\text { Selesai }\end{array}$ & 46 & 69,7 & 69,7 & \\
\hline & Sebenta & & & & \\
\hline & $\begin{array}{l}r \text {, hanya } \\
\text { beberap }\end{array}$ & 3 & 4,5 & 4,5 & 100,0 \\
\hline & Total & 66 & 100,0 & 100,0 & \\
\hline
\end{tabular}

Tabel 1. Mendeskripsikan frekuensi responden menonton tayangan video, 40,9 $\%$ menonton 1 kali, 40,9 2 kali, 15,2\% 3 kali, 1,5\% 4 kali, 1,5\% lebih dari 10 kali.

TABEL 1 FREKUENSI MENONTON (N=66)

\begin{tabular}{|ll|l|l|l|l|}
\hline & & $\begin{array}{l}\text { Frequenc } \\
\mathrm{y}\end{array}$ & $\begin{array}{l}\text { Percen } \\
\mathrm{t}\end{array}$ & $\begin{array}{l}\text { Valid } \\
\text { Percen } \\
\mathrm{t}\end{array}$ & $\begin{array}{l}\text { Cumulativ } \\
\text { e Percent }\end{array}$ \\
\hline $\begin{array}{l}\text { Vali } \\
\mathrm{d}\end{array}$ & $\begin{array}{l}1 \\
\text { kali } \\
2 \\
\text { kali }\end{array}$ & 27 & 40,9 & 40,9 & 40,9 \\
$\begin{array}{l}3 \\
\text { kali } \\
4 \\
\text { kali }\end{array}$ & 10 & 15,2 & 15,2 & 97,0 \\
$\begin{array}{l}\text { lebi } \\
\text { h } \\
\text { dari } \\
10 \\
\text { kali } \\
\text { Tota } \\
\text { l }\end{array}$ & 1 & 1,5 & 1,5 & 98,5 \\
& 66 & 1,5 & 1,5 & 100,0 \\
\hline
\end{tabular}

\begin{tabular}{|c|c|c|c|c|c|}
\hline & & $\begin{array}{c}\text { Frequenc } \\
\mathrm{y}\end{array}$ & $\begin{array}{c}\text { Perce } \\
\text { nt }\end{array}$ & $\begin{array}{c}\text { Valid } \\
\text { Perce } \\
\text { nt }\end{array}$ & $\begin{array}{l}\text { Cumulati } \\
\text { ve } \\
\text { Percent }\end{array}$ \\
\hline $\begin{array}{c}\text { Vali } \\
\text { d }\end{array}$ & $\begin{array}{c}\text { Kuran } \\
\text { g } \\
\text { Serius }\end{array}$ & 12 & 18,2 & 18,2 & 18,2 \\
\hline & $\begin{array}{l}\text { Sanga } \\
t \\
\text { Serius }\end{array}$ & 1 & 1,5 & 1,5 & 19,7 \\
\hline & Serius & 51 & 77,3 & 77,3 & 97,0 \\
\hline & $\begin{array}{l}\text { Tidak } \\
\text { Serius }\end{array}$ & 2 & 3,0 & 3,0 & 100,0 \\
\hline & Total & 66 & 100,0 & 100,0 & \\
\hline
\end{tabular}

Tabel 2. Mendeskripsikan lama atau durasi menonton. 3,0\% memutar video berulang kali, 22,7 hanya menonton sebagian, 68,7 menonton hingga selesai, dan $4,5 \%$ hanya menonton beberapa detik saja.

\section{TABEL 2 DURASI MENONTON $(\mathrm{N}=66)$}

TABEL 3 KESERIUSAN MENONTON $(\mathrm{N}=66)$

\section{Efek Kognitif}

Efek kognitif adalah efek yang

Tabel 3. Mendeskripsikan keseriusan menonton. 3,0\% tidak serius menonton, $18,2 \%$ kurang serius, $77,3 \%$ menonton dengan serius, dan $1,5 \%$ menonton sangat serius.

muncul pada diri komunikan mendapatkan penambahan informasi. Dalam efek kognitif media massa dapat membantu khalayak dalam mempelajari informasi yang bermanfaat dan mengembangkan keterampilan kognitif.(Fitriansyah, 2018).

Dari segi kelengkapan informasi, $1,5 \%$ menjawab sangat benar video Gubernur Banten berisi informasi yang 
lengkap tentang penyebaran virus Corona di Provinsi Banten, 57,6\% menjawab benar, 36,4 \% menjawab kurang benar, dan 4,5\% menjawab tidak benar. Dari sini dapat disimpulkan bahwa total responden yang berpendapat bahwa mereka mendapat informasi secara lengkap total ada 59,1 responden. Sedangkan yang tidak total $40,9 \%$ responden.

\section{TABEL 4 KELENGKAPAN INFORMASI}

\begin{tabular}{|cc|c|c|c|c|}
\hline & & $\begin{array}{c}\text { Frequenc } \\
\mathrm{y}\end{array}$ & $\begin{array}{c}\text { Perce } \\
\mathrm{nt}\end{array}$ & $\begin{array}{c}\text { Valid } \\
\text { Perce } \\
\mathrm{nt}\end{array}$ & $\begin{array}{c}\text { Cumulati } \\
\text { ve } \\
\text { Percent }\end{array}$ \\
\hline $\begin{array}{c}\text { Vali } \\
\mathrm{d}\end{array}$ & $\begin{array}{c}\text { Benar } \\
\text { Kuran } \\
\mathrm{g}\end{array}$ & 38 & 57,6 & 57,6 & 57,6 \\
$\begin{array}{c}\text { Benar } \\
\text { Sanga } \\
\mathrm{t}\end{array}$ & 1 & 1,5 & 1,5 & 95,5 \\
$\begin{array}{c}\text { Benar } \\
\text { Tidak } \\
\text { Benar } \\
\text { Total }\end{array}$ & 3 & 4,5 & 4,5 & 100,0 \\
\hline
\end{tabular}

Selanjutnya, kami bertanya bagaimana pengetahuan responden tentang efek menular virus Corona setelah menonton video Gubernur Banten. Hasilnya $71,2 \%$ percaya, $13,6 \%$ sangat percaya, $13,6 \%$ kurang percaya dan $1,5 \%$ percaya. Ini menunjukkan bahwa kesadaran responden akan bahaya penularan virus Corona sangat tinggi (Total Sangat Setuju dan Setuju $=84,8 \%$ ).

TABEL 5 EFEK MENULAR CORONA

\begin{tabular}{|c|c|c|c|c|c|}
\hline & & $\begin{array}{c}\text { Frequenc } \\
\mathrm{y}\end{array}$ & $\begin{array}{c}\text { Perce } \\
\text { nt }\end{array}$ & $\begin{array}{c}\text { Valid } \\
\text { Perce } \\
\text { nt }\end{array}$ & $\begin{array}{c}\text { Cumulati } \\
\text { ve } \\
\text { Percent }\end{array}$ \\
\hline $\begin{array}{c}\text { Vali } \\
\mathrm{d}\end{array}$ & $\begin{array}{c}\text { Kuran } \\
\text { g } \\
\text { percay } \\
\text { a }\end{array}$ & 9 & 13,6 & 13,6 & 13,6 \\
\hline & $\begin{array}{c}\text { Percay } \\
\text { a }\end{array}$ & 47 & 71,2 & 71,2 & 84,8 \\
\hline & $\begin{array}{c}\text { Sangat } \\
\text { percay } \\
\text { a }\end{array}$ & 9 & 13,6 & 13,6 & 98,5 \\
\hline & $\begin{array}{c}\text { Tidak } \\
\text { percay } \\
\text { a }\end{array}$ & 1 & 1,5 & 1,5 & 100,0 \\
\hline
\end{tabular}

Kami juga bertanya bagaimana pengetahuan responden tentang virus Corona setelah menonton video Gubernur Banten, apakah responden merasa bahwa virus Corona merupakan masalah kesehatan yang serius atau tidak?. Hasilnya 50,0 \% setuju bahwa virus Corona adalah masalah kesehatan yang serius, 40,9 \% sangat setuju, 7,6\% kurang setuju, dan $1,5 \%$ tidak setuju. Ini menunjukkan bahwa kesadaran responden akan bahaya virus Corona sangat tinggi (Total Sangat Setuju dan Setuju $=90,9 \%$ ).

TABEL 6 CORONA ADALAH MASALAH KESEHATAN SERIUS

\begin{tabular}{|c|c|c|c|c|c|}
\hline & & $\begin{array}{c}\text { Frequenc } \\
\mathrm{y}\end{array}$ & $\begin{array}{c}\text { Perce } \\
\text { nt }\end{array}$ & $\begin{array}{c}\text { Valid } \\
\text { Perce } \\
\text { nt }\end{array}$ & $\begin{array}{c}\text { Cumulati } \\
\text { ve } \\
\text { Percent }\end{array}$ \\
\hline \multirow[t]{5}{*}{$\begin{array}{c}\text { Vali } \\
\text { d }\end{array}$} & $\begin{array}{c}\text { Kuran } \\
g \\
\text { Setuju }\end{array}$ & 5 & 7,6 & 7,6 & 7,6 \\
\hline & $\begin{array}{c}\text { Sanga } \\
t \\
\text { Setuju }\end{array}$ & 27 & 40,9 & 40,9 & 48,5 \\
\hline & Setuju & 33 & 50,0 & 50,0 & 98,5 \\
\hline & $\begin{array}{l}\text { Tidak } \\
\text { Setuju }\end{array}$ & 1 & 1,5 & 1,5 & 100,0 \\
\hline & Total & 66 & 100,0 & 100,0 & \\
\hline
\end{tabular}

Kami juga bertanya tentang apakah video Gubernur Banten menjelaskan tentang gejala virus Corona? Hasilnya 42,4 \% setuju bahwa video tersebut menjelaskan gejala virus Corona, 45,5\% kurang setuju, dan $12,1 \%$ tidak setuju.

TABEL 7 PENJELASAN TENTANG GEJALA VIRUS CORONA

\begin{tabular}{|cc|c|c|c|c|}
\hline & & $\begin{array}{c}\text { Frequenc } \\
\text { y }\end{array}$ & $\begin{array}{c}\text { Palid } \\
\text { Perce } \\
\text { nt }\end{array}$ & $\begin{array}{c}\text { Perce } \\
\text { nt }\end{array}$ & $\begin{array}{c}\text { Cumulati } \\
\text { ve } \\
\text { Percent }\end{array}$ \\
\hline $\begin{array}{c}\text { Vali } \\
\text { d }\end{array}$ & $\begin{array}{c}\text { Kuran } \\
\text { g } \\
\text { Setuju } \\
\text { Setuju }\end{array}$ & 30 & 45,5 & 45,5 & 45,5 \\
& 28 & 42,4 & 42,4 & 87,9 \\
& $\begin{array}{c}\text { Tidak } \\
\text { Setuju } \\
\text { Total }\end{array}$ & 8 & 12,1 & 12,1 & 100,0 \\
& 66 & 100,0 & 100,0 & \\
\hline
\end{tabular}


Kami juga bertanya tentang apakah video Gubernur Banten menjelaskan tentang cara mencegah virus Corona? Hasilnya 48,5\% setuju bahwa video tersebut menjelaskan tentang cara mencegah virus Corona, 4,5 $\%$ sangat setuju, 40,9\% kurang setuju, dan $6,1 \%$ tidak setuju.

TABEL 8 PENJELASAN TENTANG PENCEGAHAN VIRUS CORONA

\begin{tabular}{|c|c|c|c|c|c|}
\hline & & $\begin{array}{c}\text { Frequenc } \\
\mathrm{y}\end{array}$ & $\begin{array}{c}\text { Perce } \\
\text { nt }\end{array}$ & $\begin{array}{c}\text { Valid } \\
\text { Perce } \\
\text { nt }\end{array}$ & $\begin{array}{c}\text { Cumulati } \\
\text { ve } \\
\text { Percent }\end{array}$ \\
\hline $\begin{array}{c}\text { Vali } \\
\text { d }\end{array}$ & $\begin{array}{c}\text { Kuran } \\
\text { g } \\
\text { Setuju }\end{array}$ & 27 & 40,9 & 40,9 & 40,9 \\
\hline & $\begin{array}{l}\text { Sanga } \\
\mathrm{t} \\
\text { Setuju }\end{array}$ & 3 & 4,5 & 4,5 & 45,5 \\
\hline & Setuju & 32 & 48,5 & 48,5 & 93,9 \\
\hline & $\begin{array}{l}\text { Tidak } \\
\text { Setuju }\end{array}$ & 4 & 6,1 & 6,1 & 100,0 \\
\hline & Total & 66 & 100,0 & 100,0 & \\
\hline
\end{tabular}

\section{Efek Afektif}

Efek ini menjelaskan bahwa komunikasi hanya sekedar hanya mengetahui informasi yang diterimanya, namun juga dapat merasakan efek emosional dari pesan yang di terima.(Fitriansyah, 2018).

Dalam penelitian ini kami menguji efek afekif responden setelah menonton video penjelasan Gubernur Banten Wahidin Halim tentang sebaran virus Corona di Provinsi Banten. Kami menguji apakah timbul ingatan mengerikan (kengerian), rasa cemas (kecemasan), rasa khawatir, dan rasa gelisah pada responden yang menonton video tersebut. Adapun Hasilnya adalah:

Ingatan Mengerikan. 12,1\% responden sangat setuju bahwa video penjelasan Gubernur Banten tersebut meninggalkan ingatan yang mengerikan tentang virus Corona, $42,4 \%$ setuju, 33,3\% kurang setuju, dan $12,1 \%$ tidak setuju.
TABEL 9 INGATAN YANG MENGERIKAN TENTANG VIRUS CORONA $(\mathrm{N}=66)$

\begin{tabular}{|c|c|c|c|c|c|}
\hline & & $\begin{array}{c}\text { Frequenc } \\
\mathrm{y}\end{array}$ & $\begin{array}{c}\text { Perce } \\
\text { nt }\end{array}$ & $\begin{array}{c}\text { Valid } \\
\text { Perce } \\
\text { nt } \\
\end{array}$ & $\begin{array}{c}\text { Cumulati } \\
\text { ve } \\
\text { Percent }\end{array}$ \\
\hline \multirow[t]{5}{*}{$\begin{array}{c}\text { Vali } \\
\text { d }\end{array}$} & $\begin{array}{c}\text { Kuran } \\
\mathrm{g} \\
\text { Setuju }\end{array}$ & 22 & 33,3 & 33,3 & 33,3 \\
\hline & $\begin{array}{c}\text { Sanga } \\
t \\
\text { Setuju }\end{array}$ & 8 & 12,1 & 12,1 & 45,5 \\
\hline & Setuju & 28 & 42,4 & 42,4 & 87,9 \\
\hline & $\begin{array}{l}\text { Tidak } \\
\text { Setuju }\end{array}$ & 8 & 12,1 & 12,1 & 100,0 \\
\hline & Total & 66 & 100,0 & 100,0 & \\
\hline
\end{tabular}

Sebanyak 53,0\% responden setuju bahwa video penjelasan Gubernur Banten tersebut membuat responden khawatir akan tertular virus corona, $25,8 \%$ setuju, 18,2\% kurang setuju, dan $3,0 \%$ tidak setuju.

TABEL 10 KHAWATIR TERTULAR VIRUS CORONA

\begin{tabular}{|ll|r|r|r|r|}
\hline & & $\begin{array}{r}\text { Frequenc } \\
\mathrm{y}\end{array}$ & \multicolumn{1}{c|}{$\begin{array}{r}\text { Perce } \\
\text { nt }\end{array}$} & $\begin{array}{c}\text { Valid } \\
\text { Perce } \\
\text { nt }\end{array}$ & $\begin{array}{c}\text { Cumulati } \\
\text { ve } \\
\text { Percent }\end{array}$ \\
\hline $\begin{array}{l}\text { Vali } \\
\mathrm{d}\end{array}$ & $\begin{array}{l}\text { Kuran } \\
\text { g }\end{array}$ & 12 & 18,2 & 18,2 & 18,2 \\
& $\begin{array}{l}\text { Setuju } \\
\text { Sanga } \\
\text { t }\end{array}$ & 17 & 25,8 & 25,8 & 43,9 \\
& $\begin{array}{l}\text { Setuju } \\
\text { Setuju }\end{array}$ & 35 & 53,0 & 53,0 & 97,0 \\
& $\begin{array}{l}\text { Tidak } \\
\text { Setuju } \\
\text { Total }\end{array}$ & 2 & 3,0 & 3,0 & 100,0 \\
& 66 & 100,0 & 100,0 & \\
\hline
\end{tabular}

\subsection{Rasa Gelisah}

Sebanyak 54, 5\% responden setuju bahwa video penjelasan Gubernur Banten tersebut membuat responden gelisah jika terkena demam, 30,3\% setuju, 13,6\% sangat setuju, dan $1,5 \%$ tidak setuju.

TABEL 15 GELISAH JIKA TERKENA DEMAM

\begin{tabular}{|c|c|c|c|c|}
\hline & $\begin{array}{c}\text { Frequenc } \\
\mathrm{y}\end{array}$ & $\begin{array}{c}\text { Perce } \\
\text { nt }\end{array}$ & $\begin{array}{c}\text { Valid } \\
\text { Perce } \\
\text { nt }\end{array}$ & $\begin{array}{l}\text { Cumulati } \\
\text { ve } \\
\text { Percent }\end{array}$ \\
\hline $\begin{array}{cc}\text { Vali } & \text { Kuran } \\
\text { d } & \text { g } \\
& \text { Setuju }\end{array}$ & 20 & 30,3 & 30,3 & 30,3 \\
\hline
\end{tabular}




\begin{tabular}{c|c|c|c|c|}
$\begin{array}{c}\text { Sanga } \\
\mathrm{t}\end{array}$ & 9 & 13,6 & 13,6 & 43,9 \\
$\begin{array}{c}\text { Setuju } \\
\text { Setuju }\end{array}$ & 36 & 54,5 & 54,5 & 98,5 \\
$\begin{array}{c}\text { Tidak } \\
\text { Setuju }\end{array}$ & 1 & 1,5 & 1,5 & 100,0 \\
Total & 66 & 100,0 & 100,0 & \\
\hline
\end{tabular}

Ada 45, 5\% responden kurang setuju bahwa video penjelasan Gubernur Banten tersebut membuat responden gelisah jika terkena batuk/pilek, 42,4\% setuju, 9,1\% sangat setuju, dan 3,0\% tidak setuju.

TABEL 16 GELISAH JIKA TERKENA BATUK/PILEK

\begin{tabular}{|cc|c|c|c|c|}
\hline & & $\begin{array}{c}\text { Frequenc } \\
\mathrm{y}\end{array}$ & $\begin{array}{c}\text { Palid } \\
\text { nt }\end{array}$ & $\begin{array}{c}\text { Cumulati } \\
\text { Perce } \\
\text { nt }\end{array}$ & $\begin{array}{c}\text { ve } \\
\text { Percent }\end{array}$ \\
\hline $\begin{array}{c}\text { Vali } \\
\text { d }\end{array}$ & $\begin{array}{c}\text { Kuran } \\
\text { g } \\
\text { Setuju } \\
\text { Sanga } \\
\text { t }\end{array}$ & 30 & 45,5 & 45,5 & 45,5 \\
& 6 & 9,1 & 9,1 & 54,5 \\
$\begin{array}{c}\text { Setuju } \\
\text { Setuju } \\
\text { Tidak }\end{array}$ & 28 & 42,4 & 42,4 & 97,0 \\
$\begin{array}{c}\text { Setuju } \\
\text { Total }\end{array}$ & 2 & 3,0 & 3,0 & 100,0 \\
\hline
\end{tabular}

Sebanyak 63,6\% responden setuju bahwa video penjelasan Gubernur Banten tersebut membuat responden gelisah jika terkena gangguan pernafasan, $24,4 \%$ kurang setuju, $10,6 \%$ sangat setuju, dan $1,5 \%$ tidak setuju.

TABEL 17 GELISAH JIKA TERKENA GANGGUAN PERNAFASAN

\begin{tabular}{|cc|c|c|c|c|}
\hline & $\begin{array}{c}\text { Frequenc } \\
\mathrm{y}\end{array}$ & $\begin{array}{c}\text { Perce } \\
\mathrm{nt}\end{array}$ & $\begin{array}{c}\text { Valid } \\
\text { Perce } \\
\mathrm{nt}\end{array}$ & $\begin{array}{c}\text { Cumulati } \\
\text { ve } \\
\text { Percent }\end{array}$ \\
\hline $\begin{array}{c}\text { Vali } \\
\mathrm{d}\end{array}$ & $\begin{array}{c}\text { Kuran } \\
\mathrm{g}\end{array}$ & 16 & 24,2 & 24,2 & 24,2 \\
& $\begin{array}{c}\text { Setuju } \\
\text { Sanga } \\
\mathrm{t}\end{array}$ & 7 & 10,6 & 10,6 & 34,8 \\
$\begin{array}{c}\text { Setuju } \\
\text { Setuju } \\
\text { Tidak } \\
\text { Setuju } \\
\text { Total }\end{array}$ & 42 & 63,6 & 63,6 & 98,5 \\
& 1 & 1,5 & 1,5 & 100,0 \\
\hline
\end{tabular}

Lalu 47,0\% responden setuju bahwa video penjelasan Gubernur Banten tersebut membuat responden gelisah jika sakit tenggorokan, 43,9\% kurang setuju, 7,6\% sangat setuju, dan $1,5 \%$ tidak setuju.

TABEL 18 GELISAH JIKA SAKIT TENGGOROKAN

\begin{tabular}{|c|c|c|c|c|c|}
\hline & & $\begin{array}{c}\text { Frequenc } \\
\mathrm{y}\end{array}$ & $\begin{array}{c}\text { Perce } \\
\text { nt }\end{array}$ & $\begin{array}{c}\text { Valid } \\
\text { Perce } \\
\text { nt }\end{array}$ & $\begin{array}{l}\text { Cumulati } \\
\text { ve } \\
\text { Percent }\end{array}$ \\
\hline \multirow[t]{5}{*}{$\begin{array}{c}\text { Vali } \\
\text { d }\end{array}$} & $\begin{array}{c}\text { Kuran } \\
\text { g } \\
\text { Setuju }\end{array}$ & 29 & 43,9 & 43,9 & 43,9 \\
\hline & $\begin{array}{l}\text { Sanga } \\
\text { t } \\
\text { Setuju }\end{array}$ & 5 & 7,6 & 7,6 & 51,5 \\
\hline & Setuju & 31 & 47,0 & 47,0 & 98,5 \\
\hline & $\begin{array}{l}\text { Tidak } \\
\text { Setuju }\end{array}$ & 1 & 1,5 & 1,5 & 100,0 \\
\hline & Total & 66 & 100,0 & 100,0 & \\
\hline
\end{tabular}

\subsection{Rasa Takut}

Hasil penelitian menunjukkan $45,5 \%$ responden kurang setuju bahwa setelah menonton video penjelasan Gubernur Banten tersebut responden merasa takut saat bertemu dengan orang yang demam, $42,4 \%$ kurang setuju, 7,6\% sangat setuju, dan $4,5 \%$ tidak setuju.

TABEL 23 TAKUT SAAT BERTEMU DENGAN ORANG YANG DEMAM

\begin{tabular}{|cc|c|c|c|c|}
\hline & & $\begin{array}{c}\text { Frequenc } \\
\text { y }\end{array}$ & $\begin{array}{c}\text { Perce } \\
\text { nt }\end{array}$ & $\begin{array}{c}\text { Valid } \\
\text { Perce } \\
\text { nt }\end{array}$ & $\begin{array}{c}\text { Cumulati } \\
\text { ve } \\
\text { Percent }\end{array}$ \\
\hline $\begin{array}{c}\text { Vali } \\
\text { d }\end{array}$ & $\begin{array}{c}\text { Kuran } \\
\text { g } \\
\text { Setuju } \\
\text { Sanga } \\
\text { t }\end{array}$ & 30 & 45,5 & 45,5 & 45,5 \\
& 5 & 7,6 & 7,6 & 53,0 \\
$\begin{array}{c}\text { Setuju } \\
\text { Setuju } \\
\text { Tidak } \\
\text { Setuju } \\
\text { Total }\end{array}$ & 28 & 42,4 & 42,4 & 95,5 \\
& 66 & 4,5 & 4,5 & 100,0 \\
\end{tabular}

Kemudian 42,4\% responden kurang setuju bahwa setelah menonton video penjelasan Gubernur Banten tersebut responden merasa takut saat bertemu dengan orang yang batu \& pilek, 40,9\% kurang setuju, $9,1 \%$ sangat setuju, dan 7,6\% tidak setuju.

TABEL 24 TAKUT SAAT BERTEMU ORANG YANG BATUK \& PILEK 


\begin{tabular}{|c|c|c|c|c|c|}
\hline & & $\begin{array}{c}\text { Frequenc } \\
\mathrm{y}\end{array}$ & $\begin{array}{c}\text { Perce } \\
\text { nt }\end{array}$ & $\begin{array}{c}\text { Valid } \\
\text { Perce } \\
\text { nt }\end{array}$ & $\begin{array}{l}\text { Cumulati } \\
\text { ve } \\
\text { Percent }\end{array}$ \\
\hline \multirow[t]{5}{*}{$\begin{array}{c}\text { Vali } \\
\text { d }\end{array}$} & $\begin{array}{l}\text { Kuran } \\
\text { g } \\
\text { Setuju }\end{array}$ & 28 & 42,4 & 42,4 & 42,4 \\
\hline & $\begin{array}{l}\text { Sanga } \\
\quad \mathrm{t} \\
\text { Setuju }\end{array}$ & 6 & 9,1 & 9,1 & 51,5 \\
\hline & Setuju & 27 & 40,9 & 40,9 & 92,4 \\
\hline & $\begin{array}{l}\text { Tidak } \\
\text { Setuju }\end{array}$ & 5 & 7,6 & 7,6 & 100,0 \\
\hline & Total & 66 & 100,0 & 100,0 & \\
\hline
\end{tabular}

Ada 50,0\% responden setuju bahwa setelah menonton video penjelasan Gubernur Banten tersebut responden merasa takut saat bertemu orang dengan gangguan pernafasan, $37,9 \%$ kurang setuju, 7,6\% sangat setuju, dan 4,5\% tidak setuju.

TABEL 25 TAKUT SAAT BERTEMU ORANG DENGAN GANGGUAN PERNAFASAN

\begin{tabular}{|cc|c|c|c|c|}
\hline & & $\begin{array}{c}\text { Frequenc } \\
\mathrm{y}\end{array}$ & $\begin{array}{c}\text { Perce } \\
\text { nt }\end{array}$ & $\begin{array}{c}\text { Valid } \\
\text { Perce } \\
\text { nt }\end{array}$ & $\begin{array}{c}\text { Cumulati } \\
\text { ve } \\
\text { Percent }\end{array}$ \\
\hline $\begin{array}{c}\text { Vali } \\
\mathrm{d}\end{array}$ & $\begin{array}{c}\text { Kuran } \\
\mathrm{g} \\
\text { Setuju } \\
\text { Sanga } \\
\mathrm{t}\end{array}$ & 25 & 37,9 & 37,9 & 37,9 \\
$\begin{array}{c}\text { Setuju } \\
\text { Setuju } \\
\text { Tidak } \\
\text { Setuju } \\
\text { Total }\end{array}$ & 33 & 7,6 & 7,6 & 45,5 \\
& 3 & 4,5 & 4,5 & 100,0 \\
\hline
\end{tabular}

Sedangkan $45,5 \%$ responden kurang setuju bahwa setelah menonton video penjelasan Gubernur Banten tersebut responden merasa takut saat bertemu orang yang sakit tenggorokan, $40,9 \%$ setuju, $7,6 \%$ sangat setuju, dan $6,1 \%$ tidak setuju.

TABEL 26 TAKUT SAAT BERTEMU ORANG YANG SAKIT TENGGOROKAN

\begin{tabular}{|cc|c|c|c|c|}
\hline & & $\begin{array}{c}\text { Frequenc } \\
\mathrm{y}\end{array}$ & $\begin{array}{c}\text { Palid } \\
\text { nt }\end{array}$ & $\begin{array}{c}\text { Cumulati } \\
\text { Perce } \\
\text { nt }\end{array}$ & $\begin{array}{c}\text { ve } \\
\text { Percent }\end{array}$ \\
\hline $\begin{array}{c}\text { Vali } \\
\mathrm{d}\end{array}$ & $\begin{array}{c}\text { Kuran } \\
\mathrm{g} \\
\text { Setuju } \\
\text { Sanga } \\
\text { t } \\
\text { Setuju }\end{array}$ & 30 & 45,5 & 45,5 & 45,5 \\
& 5 & 7,6 & 7,6 & 53,0 \\
\hline
\end{tabular}

\begin{tabular}{c|c|c|c|c|} 
Setuju & 27 & 40,9 & 40,9 & 93,9 \\
Tidak & 4 & 6,1 & 6,1 & 100,0 \\
$\begin{array}{c}\text { Setuju } \\
\text { Total }\end{array}$ & 66 & 100,0 & 100,0 & \\
\hline
\end{tabular}

\section{Efek Perilaku}

\subsection{Panik dan Segera ke Dokter}

Sebanyak 51,5\% responden setuju bahwa video penjelasan Gubernur Banten tersebut membuat responden panik dan akan segera ke dokter jika terkena demam, 31,8\% kurang setuju, $10,6 \%$ sangat setuju, dan $6,1 \%$ tidak setuju.

TABEL 19 PANIK JIKA TERKENA DEMAM

\begin{tabular}{|cc|c|c|c|c|}
\hline & & $\begin{array}{c}\text { Frequenc } \\
\mathrm{y}\end{array}$ & $\begin{array}{c}\text { Perce } \\
\mathrm{nt}\end{array}$ & $\begin{array}{c}\text { Valid } \\
\text { Perce } \\
\text { nt }\end{array}$ & $\begin{array}{c}\text { Cumulati } \\
\text { ve } \\
\text { Percent }\end{array}$ \\
\hline $\begin{array}{c}\text { Vali } \\
\mathrm{d}\end{array}$ & $\begin{array}{c}\text { Kuran } \\
\mathrm{g} \\
\text { Setuju } \\
\text { Sanga } \\
\mathrm{t}\end{array}$ & 21 & 31,8 & 31,8 & 31,8 \\
& 7 & 10,6 & 10,6 & 42,4 \\
$\begin{array}{c}\text { Setuju } \\
\text { Setuju } \\
\text { Tidak }\end{array}$ & 34 & 51,5 & 51,5 & 93,9 \\
$\begin{array}{c}\text { Setuju } \\
\text { Total }\end{array}$ & 4 & 6,1 & 6,1 & 100,0 \\
\hline
\end{tabular}

Dan $47,0 \%$ responden setuju bahwa video penjelasan gubernur banten tersebut membuat responden panik dan akan segera ke dokter jika terkena batuk/pilek, 36,4\% kurang setuju, $10,6 \%$ sangat setuju, dan $6,1 \%$ tidak setuju.

TABEL 20 PANIK JIKA TERKENA BATUK/PILEK

\begin{tabular}{|cc|c|c|c|c|}
\hline & & $\begin{array}{c}\text { Frequenc } \\
\mathrm{y}\end{array}$ & $\begin{array}{c}\text { Perce } \\
\text { nt }\end{array}$ & $\begin{array}{c}\text { Valid } \\
\text { Perce } \\
\text { nt }\end{array}$ & $\begin{array}{c}\text { Cumulati } \\
\text { ve } \\
\text { Percent }\end{array}$ \\
\hline $\begin{array}{c}\text { Vali } \\
\text { d }\end{array}$ & $\begin{array}{c}\text { Kuran } \\
\text { g } \\
\text { Setuju } \\
\text { Sanga } \\
\text { t } \\
\text { Setuju }\end{array}$ & 24 & 36,4 & 36,4 & 36,4 \\
& 7 & 10,6 & 10,6 & 47,0 \\
$\begin{array}{c}\text { Setuju } \\
\text { Tidak }\end{array}$ & 31 & 47,0 & 47,0 & 93,9 \\
& 4 & 6,1 & 6,1 & 100,0 \\
Setuju & Total & 66 & 100,0 & 100,0 & \\
\hline
\end{tabular}


Hasil penelitian juga mengungkapkan $59,1 \%$ responden setuju bahwa video penjelasan Gubernur Banten tersebut membuat responden panik dan akan segera ke dokter jika terkena gangguan pernafasan, 25,8\% kurang setuju, 10,6\% sangat setuju, dan $4,5 \%$ tidak setuju.

TABEL 21 PANIK JIKA TERKENA GANGGUAN PERNAFASAN

\begin{tabular}{|c|c|c|c|c|c|}
\hline & & $\begin{array}{c}\text { Frequenc } \\
\mathrm{y}\end{array}$ & $\begin{array}{c}\text { Perce } \\
\text { nt }\end{array}$ & $\begin{array}{c}\text { Valid } \\
\text { Perce } \\
\text { nt }\end{array}$ & $\begin{array}{l}\text { Cumulati } \\
\text { ve } \\
\text { Percent }\end{array}$ \\
\hline \multirow[t]{5}{*}{$\begin{array}{c}\text { Vali } \\
\text { d }\end{array}$} & $\begin{array}{c}\text { Kuran } \\
\mathrm{g} \\
\text { Setuju }\end{array}$ & 17 & 25,8 & 25,8 & 25,8 \\
\hline & $\begin{array}{c}\text { Sanga } \\
t \\
\text { Setuju }\end{array}$ & 7 & 10,6 & 10,6 & 36,4 \\
\hline & Setuju & 39 & 59,1 & 59,1 & 95,5 \\
\hline & $\begin{array}{l}\text { Tidak } \\
\text { Setuju }\end{array}$ & 3 & 4,5 & 4,5 & 100,0 \\
\hline & Total & 66 & 100,0 & 100,0 & \\
\hline
\end{tabular}

Sementara 54,5\% responden setuju bahwa video penjelasan Gubernur Banten tersebut membuat responden panik dan akan segera ke dokter jika terkena gangguan pernafasan, 34,8\% kurang setuju, 7,6\% sangat setuju, dan 3,0\% tidak setuju.

TABEL 22 PANIK JIKA SAKIT TENGGOROKAN

\begin{tabular}{|c|c|c|c|c|c|}
\hline & & $\begin{array}{c}\text { Frequenc } \\
\mathrm{y}\end{array}$ & $\begin{array}{c}\text { Perce } \\
\text { nt }\end{array}$ & $\begin{array}{c}\text { Valid } \\
\text { Perce } \\
\text { nt }\end{array}$ & $\begin{array}{c}\text { Cumulati } \\
\text { ve } \\
\text { Percent }\end{array}$ \\
\hline \multirow[t]{5}{*}{$\begin{array}{c}\text { Vali } \\
\text { d }\end{array}$} & $\begin{array}{c}\text { Kuran } \\
\text { g } \\
\text { Setuju }\end{array}$ & 23 & 34,8 & 34,8 & 34,8 \\
\hline & $\begin{array}{c}\text { Sanga } \\
\mathrm{t} \\
\text { Setuiu }\end{array}$ & 5 & 7,6 & 7,6 & 42,4 \\
\hline & Setuju & 36 & 54,5 & 54,5 & 97,0 \\
\hline & $\begin{array}{l}\text { Tidak } \\
\text { Setuju }\end{array}$ & 2 & 3,0 & 3,0 & 100,0 \\
\hline & Total & 66 & 100,0 & 100,0 & \\
\hline
\end{tabular}

\subsection{Curiga}

Menurut penelitian, 39,4\% responden kurang setuju bahwa video penjelasan Gubernur Banten tersebut membuat responden curiga terhadap orang yang demam, $37,9 \%$ setuju, $12,1 \%$ tidak setuju, dan $10,6 \%$ sangat setuju.

TABEL 11 CURIGA TERHADAP ORANG YANG DEMAM

\begin{tabular}{|cc|c|c|c|c|}
\hline & & $\begin{array}{c}\text { Frequenc } \\
\mathrm{y}\end{array}$ & $\begin{array}{c}\text { Perce } \\
\mathrm{nt}\end{array}$ & $\begin{array}{c}\text { Valid } \\
\text { Perce } \\
\mathrm{nt}\end{array}$ & $\begin{array}{c}\text { Cumulati } \\
\text { ve } \\
\text { Percent }\end{array}$ \\
\hline $\begin{array}{c}\text { Vali } \\
\mathrm{d}\end{array}$ & $\begin{array}{c}\text { Kuran } \\
\mathrm{g}\end{array}$ & 26 & 39,4 & 39,4 & 39,4 \\
$\begin{array}{c}\text { Setuju } \\
\text { Sanga } \\
\mathrm{t}\end{array}$ & 7 & 10,6 & 10,6 & 50,0 \\
$\begin{array}{c}\text { Setuju } \\
\text { Setuju } \\
\text { Tidak }\end{array}$ & 25 & 37,9 & 37,9 & 87,9 \\
$\begin{array}{c}\text { Setuju } \\
\text { Total }\end{array}$ & 8 & 12,1 & 12,1 & 100,0 \\
\hline
\end{tabular}

Sementara 50,0\% responden kurang setuju bahwa video penjelasan Gubernur Banten tersebut membuat responden curiga terhadap orang yang batuk atau pilek, $34,8 \%$ setuju, 7,6\% tidak setuju, dan 7,6\% sangat setuju.

TABEL 12 CURIGA TERHADAP ORANG YANG BATUK \& PILEK

\begin{tabular}{|ll|r|r|r|r|}
\hline & & $\begin{array}{r}\text { Frequenc } \\
\mathrm{y}\end{array}$ & \multicolumn{1}{c|}{$\begin{array}{c}\text { Perce } \\
\mathrm{nt}\end{array}$} & \multicolumn{1}{c|}{$\begin{array}{c}\text { Valid } \\
\text { Perce } \\
\text { nt }\end{array}$} & $\begin{array}{c}\text { Cumulati } \\
\text { ve } \\
\text { Percent }\end{array}$ \\
\hline $\begin{array}{l}\text { Vali } \\
\mathrm{d}\end{array}$ & $\begin{array}{l}\text { Kuran } \\
\text { g }\end{array}$ & 33 & 50,0 & 50,0 & 50,0 \\
& $\begin{array}{l}\text { Setuju } \\
\text { Sanga } \\
\text { t }\end{array}$ & 5 & 7,6 & 7,6 & 57,6 \\
& $\begin{array}{l}\text { Setuju } \\
\text { Setuju } \\
\text { Tidak }\end{array}$ & 23 & 34,8 & 34,8 & 92,4 \\
$\begin{array}{l}\text { Setuju } \\
\text { Total }\end{array}$ & 5 & 7,6 & 7,6 & 100,0 \\
\hline
\end{tabular}

Lalu 57,6\% responden kurang setuju bahwa video penjelasan Gubernur Banten tersebut membuat responden curiga terhadap orang yang sakit tenggorokan, $27,3 \%$ setuju, $9,1 \%$ tidak setuju, dan $6,1 \%$ sangat setuju.

TABEL 13 CURIGA TERHADAP ORANG YANG SAKIT TENGGOROKAN

\begin{tabular}{|c|c|c|c|c|}
\hline & Frequenc & Perce & Valid & Cumulati \\
& $\mathrm{y}$ & $\mathrm{nt}$ & $\mathrm{nt}$ & ve \\
\end{tabular}




\begin{tabular}{|cc|c|c|c|c|}
\hline $\begin{array}{c}\text { Vali } \\
\mathrm{d}\end{array}$ & $\begin{array}{c}\text { Kuran } \\
\mathrm{g} \\
\text { Setuju } \\
\text { Sanga } \\
\mathrm{t}\end{array}$ & 38 & 57,6 & 57,6 & 57,6 \\
& 4 & 6,1 & 6,1 & 63,6 \\
$\begin{array}{c}\text { Setuju } \\
\text { Setuju }\end{array}$ & 18 & 27,3 & 27,3 & 90,9 \\
$\begin{array}{c}\text { Tidak } \\
\text { Setuju }\end{array}$ & 6 & 9,1 & 9,1 & 100,0 \\
Total & 66 & 100,0 & 100,0 & \\
\hline
\end{tabular}

Sedangkan 47,0\% responden kurang setuju bahwa video penjelasan Gubernur Banten tersebut membuat responden curiga terhadap orang dengan gangguan pernafasan, $37,9 \%$ setuju, 7,6\% tidak setuju, dan $7,6 \%$ sangat setuju.

TABEL 14 CURIGA TERHADAP ORANG DENGAN GANGGUAN PERNAFASAN

\begin{tabular}{|cc|c|c|c|c|}
\hline & & $\begin{array}{c}\text { Frequenc } \\
\mathrm{y}\end{array}$ & $\begin{array}{c}\text { Perce } \\
\text { nt }\end{array}$ & $\begin{array}{c}\text { Valid } \\
\text { Perce } \\
\text { nt }\end{array}$ & $\begin{array}{c}\text { Cumulati } \\
\text { ve } \\
\text { Percent }\end{array}$ \\
\hline $\begin{array}{c}\text { Vali } \\
\text { d }\end{array}$ & $\begin{array}{c}\text { Kuran } \\
\text { g }\end{array}$ & 31 & 47,0 & 47,0 & 47,0 \\
& $\begin{array}{c}\text { Setuju } \\
\text { Sanga } \\
\text { t }\end{array}$ & 5 & 7,6 & 7,6 & 54,5 \\
& $\begin{array}{c}\text { Setuju } \\
\text { Setuju }\end{array}$ & 25 & 37,9 & 37,9 & 92,4 \\
& Tidak & 5 & 7,6 & 7,6 & 100,0 \\
& $\begin{array}{c}\text { Setuju } \\
\text { Total }\end{array}$ & 66 & 100,0 & 100,0 & \\
\hline
\end{tabular}

\section{DISKUSI DAN KESIMPULAN}

\section{Efek Kognitif}

TABEL 31. EFEK KO

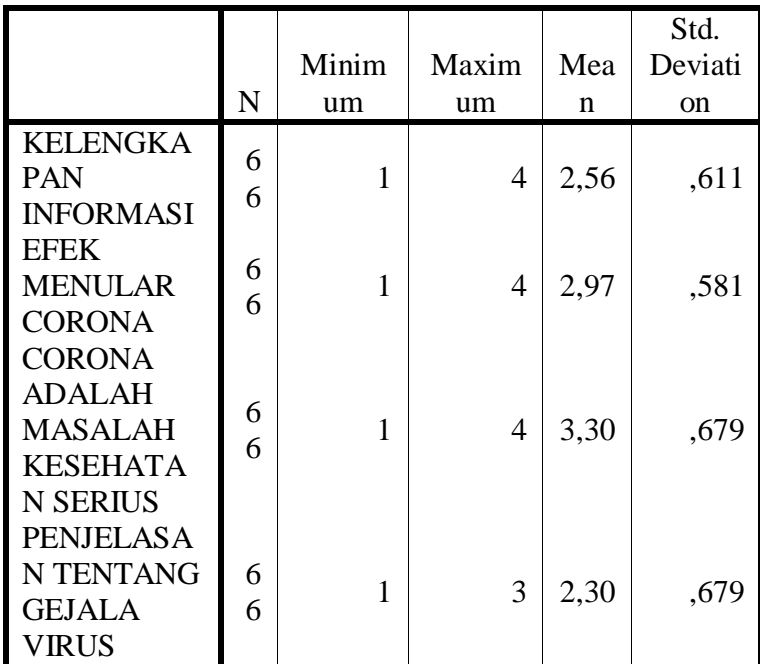

\begin{tabular}{|l|l|l|l|l|l|} 
CORONA & & & & & \\
PENJELASA & & & & & \\
N TENTANG & 6 & 1 & 4 & 2,52 &, 685 \\
PENCEGAH & 6 & 1 & & & \\
AN VIRUS & & & & & \\
CORONA & & 6 & & & \\
Valid N & & & \\
(listwise) & 6 & & & & \\
\hline
\end{tabular}

*Mean= 1 (tidak setuju) sampai 4 (sangat setuju)

Kajian ini juga telah menguji efek kognitif dan afektif responden setelah menonton video penjelasan Gubernur Banten tentang kasus Corona di Provinsi Banten. Data pada tabel. 31 menunjukkan bahwa, dalam konteks efek penambahan informasi (efek kognitif) dari video tersebut efek kognitif paling besar adalah responden mengetahui bahwa virus Corona adalah masalah kesehatan yang sangat serius $(M=3,30)$.

\section{Efek Afektif}

\section{Descriptive Statistics}

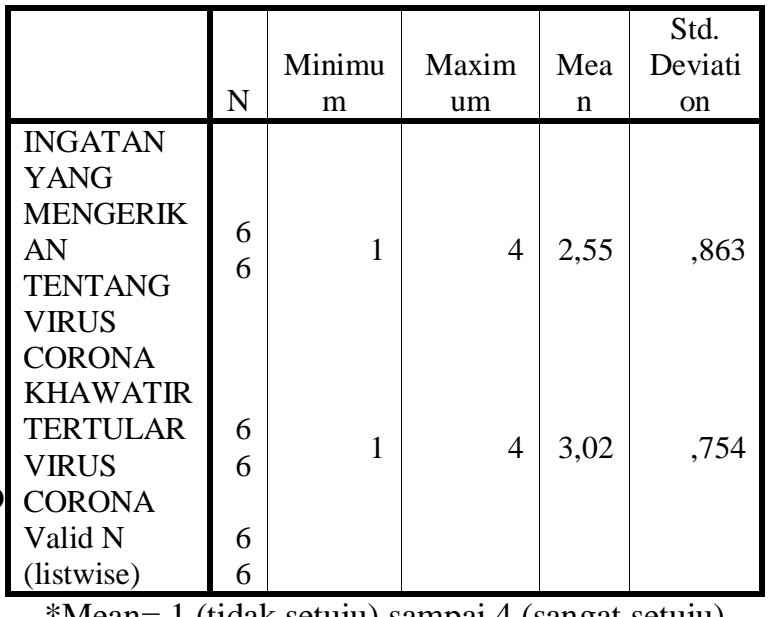

*Mean= 1 (tidak setuju) sampai 4 (sangat setuju)

Data pada tabel. 31 menunjukkan bahwa, dari konteks efek emosional (efek afektif) video tersebut, yang paling besar adalah kekhawatiran responden akan tertular oleh Virus Corona $(\mathrm{M}=3,02)$.

Efek afektif juga kami ekplorasi pada 5 emosi: Curiga, Gelisah, Panik, Takut, dan Termotivasi adapun hasilnya adalah:

\section{Rasa Gelisah}


Descriptive Statistics

\begin{tabular}{|c|c|c|c|c|c|}
\hline & $\mathrm{N}$ & $\begin{array}{l}\text { Minim } \\
\text { um }\end{array}$ & $\begin{array}{c}\text { Maxim } \\
\text { um }\end{array}$ & $\begin{array}{l}\mathrm{Me} \\
\text { an }\end{array}$ & $\begin{array}{c}\text { Std. } \\
\text { Deviati } \\
\text { on }\end{array}$ \\
\hline$\overline{\text { GELISAH }}$ & & \multirow{6}{*}{1} & \multirow{6}{*}{4} & \multirow{6}{*}{2,80} & \multirow{6}{*}{ 684 } \\
\hline JIKA & 6 & & & & \\
\hline TERKENA & 6 & & & & \\
\hline DEMAM & & & & & \\
\hline GELISAH & & & & & \\
\hline JIKA & & & & & \\
\hline TERKENA & $\begin{array}{l}6 \\
6\end{array}$ & \multirow[t]{5}{*}{1} & \multirow[t]{5}{*}{4} & \multirow[t]{5}{*}{2,58} & \multirow[t]{5}{*}{,703 } \\
\hline BATUK/PILE & & & & & \\
\hline $\mathrm{K}$ & & & & & \\
\hline GELISAH & & & & & \\
\hline JIKA & & & & & \\
\hline TERKENA & 6 & \multirow{4}{*}{1} & \multirow{4}{*}{4} & \multirow{4}{*}{2,83} & \multirow{4}{*}{,622 } \\
\hline GANGGUAN & 6 & & & & \\
\hline PERNAFASA & & & & & \\
\hline $\begin{array}{l}\mathrm{N} \\
\text { GELISAH }\end{array}$ & & & & & \\
\hline JIKA SAKIT & 6 & \multirow{5}{*}{1} & \multirow{5}{*}{4} & \multirow{5}{*}{2,61} & \multirow{5}{*}{653} \\
\hline TENGGORO & 6 & & & & \\
\hline KAN & & & & & \\
\hline Valid N & 6 & & & & \\
\hline (listwise) & 6 & & & & \\
\hline
\end{tabular}

*Mean= 1 (tidak setuju) sampai 4 (sangat setuju)

Kegelisahan paling besar responden adalah terhadap orang yang terkena gangguan pernafasan $(M=2,47)$. Responden gelisah bahwa orang terkena gangguan pernafasan sudah tertular virus Corona.

\section{Rasa Takut}

Descriptive Statistics

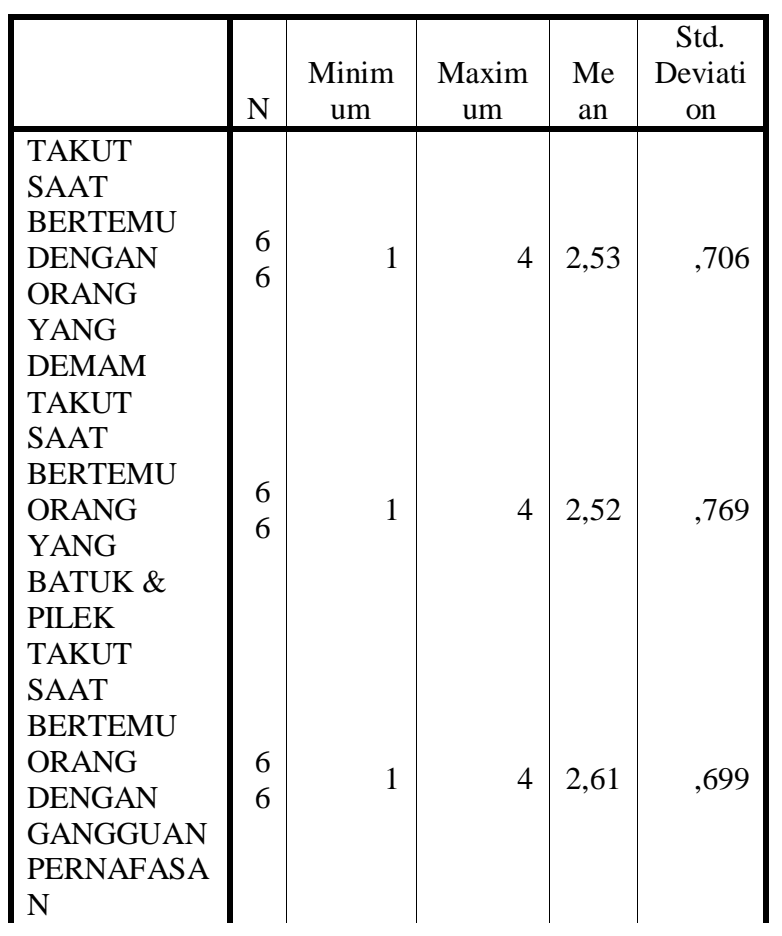

\begin{tabular}{|c|c|c|c|c|}
\hline $\begin{array}{l}\text { TAKUT } \\
\text { SAAT } \\
\text { BERTEMU } \\
\text { ORANG } \\
\text { YANG } \\
\text { SAKIT } \\
\text { TENGGORO } \\
\text { KAN } \\
\text { Valid N } \\
\text { (listwise) }\end{array}$ & $\begin{array}{l}6 \\
6\end{array}$ & 1 & 4 & 2,50 \\
\hline
\end{tabular}

Ketakutan paling besar responden adalah terhadap orang yang terkena gangguan pernafasan $(M=2,61)$. Responden takut bahwa orang terkena gangguan pernafasan sudah tertular virus Corona.

\section{Efek Perilaku}

Panik dan Segera ke Dokter

Descriptive Statistics

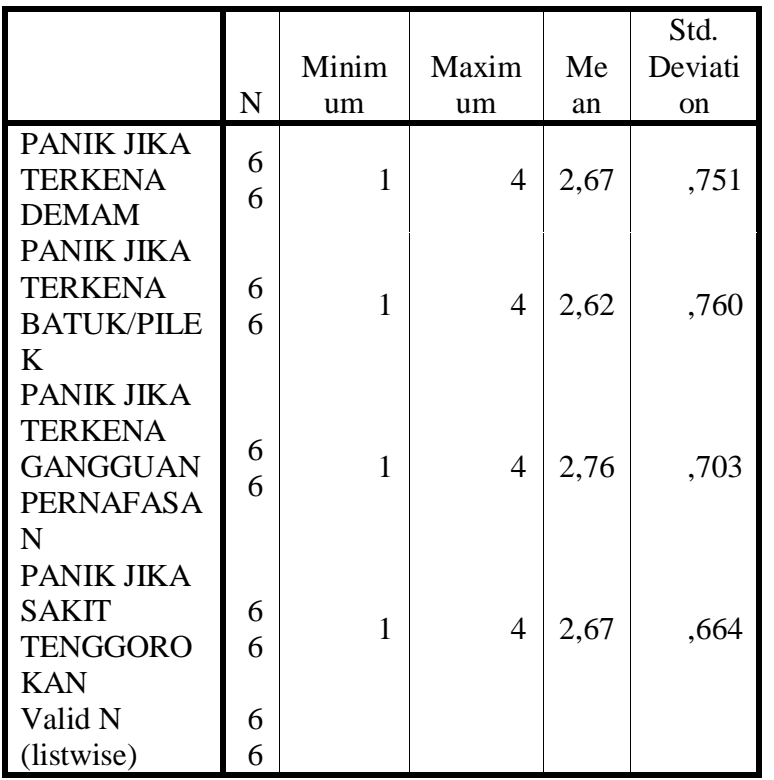

Kepanikan paling besar responden adalah terhadap orang yang terkena gangguan pernafasan $(M=2,76)$. Responden panik bahwa orang terkena gangguan pernafasan sudah tertular virus Corona.

\section{Curiga}

\section{Descriptive Statistics}

\begin{tabular}{|l|l|r|r|r|c|}
\hline & $\mathrm{N}$ & $\begin{array}{c}\text { Minim } \\
\text { um }\end{array}$ & $\begin{array}{c}\text { Maxim } \\
\text { um }\end{array}$ & $\begin{array}{c}\text { Me } \\
\text { an }\end{array}$ & $\begin{array}{c}\text { Std. } \\
\text { Deviati } \\
\text { on }\end{array}$ \\
\hline $\begin{array}{l}\text { CURIGA } \\
\text { ORRHADAP }\end{array}$ & 6 & 1 & 4 & 2,47 &, 845 \\
\hline
\end{tabular}




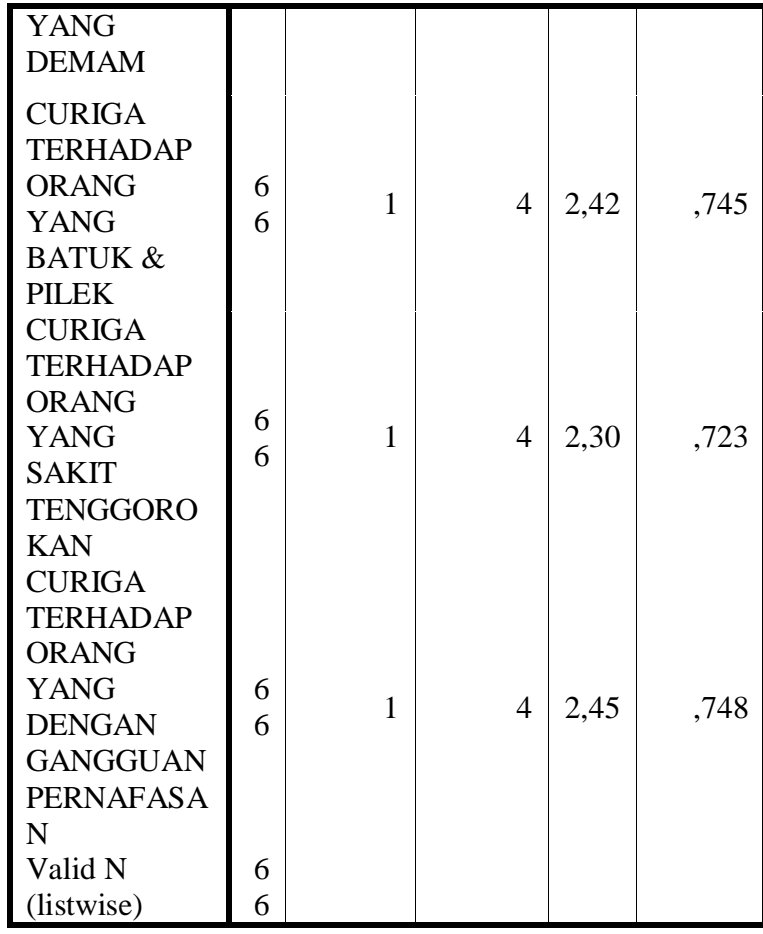

*Mean= 1 (tidak setuju) sampai 4 (sangat setuju)

Kecurigaan paling besar responden adalah terhadap orang yang demam $(\mathrm{M}=2,47)$. Responden curiga bahwa orang yang demam sudah tertular virus Corona.

Dari data ini dapat disimpulkan bahwa sebaran video pernyataan Gubernur Banten Wahidin Halim tentang kasus di provinsi Banten berefek besar terhadap kognisi responden. Hal ini terlihat dari rata-rata jawaban tingkat persetujuan responden yang tinggi $(M=2,30-3,30)$ bahwa mereka mendapatkan tambahan informasi dari video tersebut.

Efek besar juga terlihat pada afeksi responden, rata-rata jawaban tingkat persetujuan responden terhitung tinggi $(\mathrm{M}=2,50-3,02)$ mulai hadirnya ingatan yang mengerikan, takut tertular, gelisah, hingga takut terhadap orang-orang yang sakit dengan gejala seperti terkena virus Corona.

Sedangkan pada perilaku, video tersebut juga berefek besar, terlihat dari rata-rata jawaban tingkat persetujuan responden yang tinggi $(M=2,30$ - 2,76) pada munculnya perilaku panik dan curiga responden.

Dengan demikian dapat disimpulkan bahwa sebaran video pernyataan Gubernur Banten Wahidin Halim tentang kasus di provinsi Banten berefek besar pada efek kognitif, afektif dan perilaku responden.

\section{REFERENSI}

\section{Buku}

Effendy, Onong Ucjhana. 2003. Ilmu, Teori, dan Filsafat Komunikasi. Bandung: Simbiosa Rektama Media.

Mulyana, Deddy. 2016. Ilmu Komunikasi Suatu Pengantar. Bandung: PT Remaja Rosdakarya.

\section{Jurnal}

Fitriansyah, Fifit. 2018.Efek Komunikasi Massa Pada Khalayak (Studi Deskriptif Penggunaan Media Sosial dalam Membentuk Perilaku Remaja). Jurnal Humaniora Bina Sarana Informatika, Volume 18 No. 2. $171-178$

Annisa, Dona Fitri. Ifdil. 2016. Konsep Kecemasan (Anxiety) pada Lanjut Usia (Lansia). Konselor. Volume 5 | Number 2 | June 2016

\section{Website}

https://banten.suara.com/read/2020/03/12/

213435/kemenkes-data-pasien-viruscorona-bukan-untuk-diumumkangubernur

https://nasional.tempo.co/read/1318917/pe merintah-persoalkan-data-gubernurbanten-soal-warga-kenacorona/full\&view $=$ ok

https://regional.kompas.com/read/2020/03/ 12/18571081/gubernur-banten- 
umumkan-dua-warganya-positifcorona? page $=$ all\#source $=$ clicktitle https://www.liputan6.com/news/read/4200 557/gubernur-wahidin-halim-ada-2warga-banten-positif-covid-19 